\title{
Water bodies of Altai Krai (Russia): the condition analysis and quality improvement opportunities
}

\author{
Oksana Korovina, Vladimir Somin*, and Larisa Komarova \\ Polzunov Altai State Technical University, 656038, Barnaul, Russia
}

\begin{abstract}
The characteristics of surface and groundwater of the Altai Territory (Russia) are considered, the possibility of using groundwater of various horizons for domestic use is evaluated. The pollution of water bodies by compounds of heavy metals and oil products is analyzed.
\end{abstract}

\section{Introduction}

Altai Krai is situated in the southeast of Western Siberia. According to the type of relief its territory is divided into the northwest - plain part and southeast - mountainous one. The plain part of the Altai Territory hydrographically includes two types of water bodies: the $\mathrm{Ob}$ river basin and basins of the closed internal flow of the Kulundinskaya plain. The total length of the rivers of the first part is 91 thousand $\mathrm{km}^{2}$. Approximately $90 \%$ of this value falls on the waterways up to $100 \mathrm{~km}$ long and $10 \%$ - on the rivers more than $100 \mathrm{~km}$ long. There are about 17,000 rivers in the Altai Territory, the majority of which belong to the hydro carbonate class with mineralization of $100-300 \mathrm{mg} / \mathrm{dm}^{3}$. There are more than 11 thousand lakes in the region, $60 \%$ of which are fresh, and the rest lakes are salt and bitter ones. The lakes with the highest mineralization (more than $50 \mathrm{~g} / \mathrm{l}$ ) belong to the Kulundinskaya plain and southwestern part of Kasmalinskaya plain. The chemical composition is chloride-sulfate, sodium-magnesium; chloride, sodium: chloride and sulfatechloride, sodium-magnesium are less common [1].

To accumulate river flow in the region 73 reservoirs with a volume of more than 1 million $\mathrm{m}^{3}$ are used. To supply water to the steppe regions the Kulundinsky main canal with a length of $180 \mathrm{~km}$ and the main channel of the Aleisk irrigation system with a length of $90 \mathrm{~km}$ were built.

The West Siberian platform is one of the largest artesian basins in the world, accumulating huge groundwater resources. Within the plain area of the region there are artesian basins of the 2nd order: the Verkhne-Obsky and Kulundinsko-Barnaulsky basins. Mineralization increases with depth, and the hydrocarbonate, calcium, magnesium type is replaced by sulfate-hydrocarbonate, calcium, magnesium, sodium-potassium types. In Kulundinsko-Barnaulsky artesian basin, in the area of forest-steppes and steppes mineralization, hardness (content of calcium and magnesium ions) of groundwater is the highest one.

\footnotetext{
* Corresponding author: vladimir_somin@mail.ru
} 
In the steppe zone of the region there is moisture deficit with a predominance of evaporation over filtration: salinity is widespread here. It is observed in all components of geological environments: soils, grounds, peat, underground, lake, marsh, river and soil waters as well as plants. In the first from the surface aquifer complex groundwater salinity varies from $1 \mathrm{~g} / 1$ to $1.5 \mathrm{~g} / 1$ and refers to hydrocarbonate, sulfate-hydrocarbonate, chloridehydrocarbonate sodium-potassium, calcium, magnesium types. With depth in the lower aquifers, where water exchange is difficult, salinity increases to 4-10 g/l, and the type of water changes to sulfate, chloride-sulfate, chloride sodium-potassium, calcium types [2].

With $\mathrm{pH}$ decrease in acidic environment in groundwaters there is an increase in the contents of zinc, manganese, lead, antimony, titanium, and, conversely, in an alkaline environment the content of these elements decreases. Within the forest-steppe zone due to leaching processes there are signs of salinization. Relatively high iron contents are observed which are explained by the presence of significant quantity of organic substances and more intensive dissolution of iron ore deposits [3].

The combination of two hydrogeological structures, significant roughness of the relief, and locations of ores determined the uniqueness of the hydrochemical composition of groundwater which are the sources for household and drinking water supply in Altai Krai. At the same time many rivers are waste water receivers [4].

The rivers water quality to a large extent depends on the intensity of precipitation, snowmelt, as well as sewage pollution and industrial wastewaters that enter the water bodies through concentrated and dispersed discharges from the territories of settlements, agricultural and industrial enterprises. In Altai Krai there are 48 industrial wastewater outlets to the Alei, Biya, Chumysh, Barnaulka, Ob, Charysh, Katun rivers, and about a third of the industrial wastewaters and storm waters from enterprises of the region are discharged into water bodies without adequate treatment. Till present the entry of pesticides and fertilizers with surface runoffs is a major source of water pollution.

Natural sources of pollutants entering water bodies are determined by the natural processes of organic matter export from the surface of watersheds, rocks leaching, soil erosion, feeding rivers with soil and groundwater containing various chemical elements and compounds, including hydrocarbons, similar in composition to petroleum products.

\section{Results}

The statistical data analysis showed that oil products, total iron and volatile phenols remain the main substances responsible for the pollution of surface waters over the past few years. However, it could be noted that for the period from 2009 to 2018 polluted wastewater discharge into surface water bodies of the Altai Territory decreased by $30 \%$, what had a positive impact on the water resources quality and the environment condition [5].

The water quality in reservoirs used for public water supply, including the $\mathrm{Ob}$ water, remains rather low.

The proportion of water samples that do not comply with hygienic standards remains significant in the past few years and amounts to more than $15 \%$ (Fig.).

The main sources of water pollution are wastewaters from enterprises of chemical, metallurgical, machine-building, processing and food industries, agricultural runoff, livestock farms and domestic sewage.

The current level of wastewater treatment is insufficient. Often after biological treatment in wastewater there is still a significant amount of nitrates and phosphates, which causes eutrophication of separate water bodies, reservoirs, in the first turn.

Wastewater of industrial enterprises in the Altai Territory is substantially contaminated with oil products, phenols, suspended solids, ions of heavy and non-ferrous metals, causing 
great damage to human health and the ecosystems of the region on the whole. Entering water bodies, effluents lower natural water quality

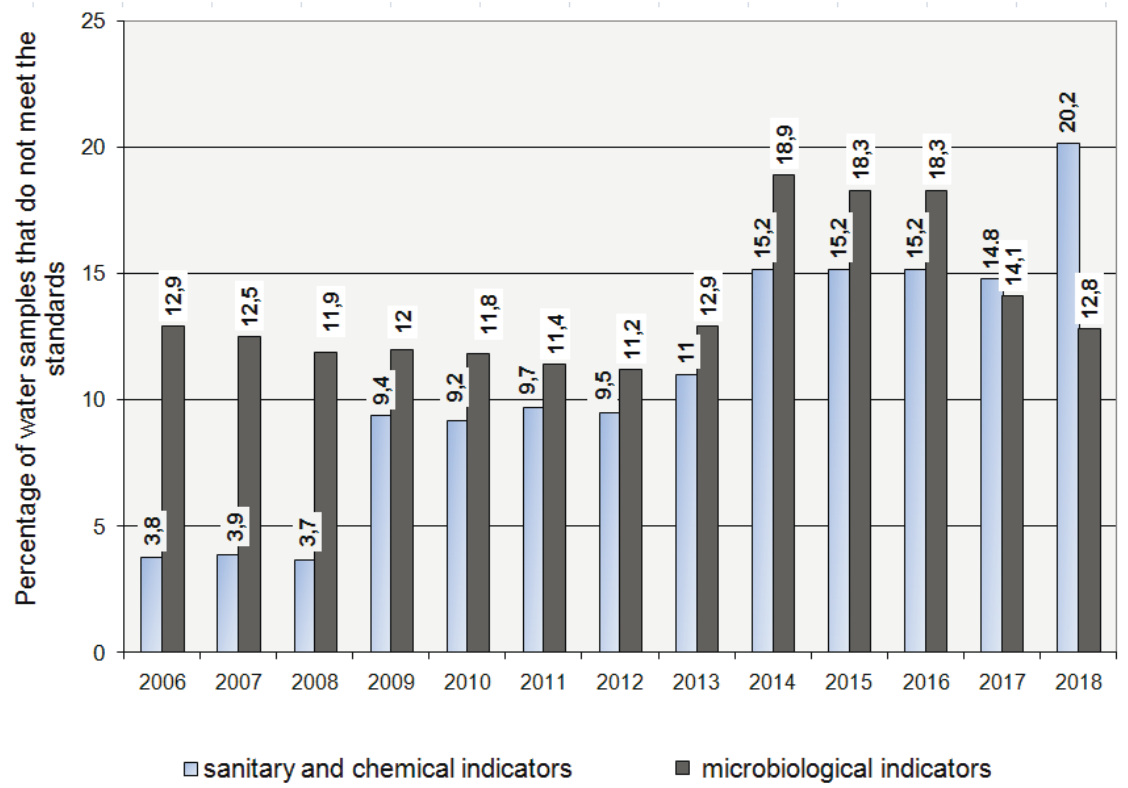

Fig. Water quality indicators for water bodies.

The priority pollutant in the reservoirs of the Altai territory is oil products. Unfortunately, so far only a small part of the region's water bodies has been covered by the monitoring network. Nevertheless, for those pollutants of which regular observations are carried out, the excess of average annual concentrations is higher than the permissible values, in some years by 10-18 times. The content of copper ions discharged with wastewater from engineering and ore processing enterprises also often exceeds maximum permissible concentrations by $1.5-4.5$ times.

Given that for the period from 2009 to 2018 the discharge of polluted wastewater into the surface water bodies of the Altai Territory decreased by $30 \%$, it can be concluded that the measures currently taken for wastewater treatment are insufficient. The greatest contribution to the pollution of water bodies is made by substances that are discharged in small quantities.

The entry into the water bodies of industrial and domestic wastewater is one of the reasons for their pollution by mineral, biogenic and organic substances, many of which are toxic. The current level of wastewater treatment is insufficient, often treated effluents contain significant amount of nitrates and phosphates, which causes the eutrophication of individual reservoirs and reservoirs. The presence of heavy metals in groundwater is associated with the dissolution of salts from sedimentary rocks, leaching of weathering products of rocks and anthropogenic factors. The main reasons for the low quality of water used by the population are natural factors, high wear of water supply networks and structures, which leads to a decrease in the quality of water supply.

In the underground waters of a number of regions, an increased content of iron compounds was noted. Many drinking water samples contain a significant amount of manganese compounds.

Nitrogenous substances, oil products, sulfates, chlorides, some heavy metals, phenols, as well as hardness are emitted from groundwater pollution. 
There are a lot of geochemical anomalies of hazardous chemical elements in soils, bottom sediments, and underground waters. All of them are associated with mineral deposits, among which mainly gold, polymetals, mercury and tungsten. In such deposits, the concentrations of copper, lead, zinc in soils reach very high values and can pollute groundwater.

The natural salt composition of groundwater in the Kulundinskaya Plain is characterized by high salinity. In this regard, in these areas there is an increased incidence of the population of urolithiasis.

Since the population and industry of these areas consume mainly groundwater, the need for its softening is obvious. At the same time, the degree of softening should correspond to the needs of consumers, in particular, for drinking purposes, hardness should not exceed $7 \mathrm{mq} / \mathrm{l}$. For enterprises, the requirements for stiffness content are usually higher, which requires a more complex organization of the water treatment.

\section{Conclusion}

Thus, the long-term functioning of environmentally dirty technologies in industry and agriculture, the discharge of insufficiently treated municipal wastewater, the inflow of pollutants with dispersed runoff from catchment areas led to widespread pollution of the region's surface water bodies and to a deterioration in the water quality in them.

This work was performed under the RFBR grant No. 17-45-220090\17 «Ensuring the environmentally safe water use of the Altai Territory using new sorption-ion-exchange materials».

\section{References}

1. V.I. Kormakov, L.F. Komarova Water resources of the Altai Territory: quality, use, protection, $164 \mathrm{P}$ (2007).

2. V.I. Zanosova, S.V. Makarychev, N.I. Aleshin Environmental aspects of agricultural water use in Altai Krai, 386 P (2012)

3. V.A. Somin, V.I. Zanosova, L.F. Komarova Water resources, 43, PP. 121-128 (2016)

4. V.I. Zanosova, O.S. Borzilov Water treatment, water supply, 7, PP. 12-16 (2013)

5. State report «On the State and Environmental Protection in the Altai Territory». Barnaul, (2008 -2018).

6. N.V. Stoyashcheva, I.D. Rybkina Water resources, 41, PP. 1-7 (2014) 